\title{
The Green State in Transition: Reply to Bailey, Barry and Craig
}

Robyn Eckersley

\section{Introduction}

The distinctive research program on the green state started to cohere soon after the New Millennium, in the wake of two major Earth summits in 1992 and 2002, a triumphant liberalism following the end of the Cold War and a new mood of cosmopolitanism that surfaced in the globalisation debates of the 1990s. In this context, both sociological and empirical accounts of the development of the environmental state (eg. Lundqvist 2001, 2004; Mol and Spaargaren 2002; Hunold and Dryzek 2002; Schnaiberg et al. 2002; Meadowcroft 2005, 2008, 2012; Paehlke and Torgerson 2005) as well as critical normative accounts of the green state (e.g. Eckersley 2004; Barry and Eckersley 2005) assumed (either explicitly or implicitly) that more ecologically responsible states were evolving out of, and transforming, liberal democratic states. ${ }^{1}$

\footnotetext{
${ }^{1}$ The terms 'environmental state' or 'ecostate' are commonly used in sociological and empirical research on the environmental functions of the state (particularly, but not only, in North America), while the 'green state' is more commonly used to refer to a critical and normative project of building ecologically responsible states to the point that ecological sustainability is a central purpose of the state. However, this usage is not consistent and critical theories of the 'green state' combine normative theory with sociological and empirical research on the environmental state.
} 
Yet even before the end of the first decade of the New Millennium, the domestic and international context began to shift, along with the political prospects for the further greening of states. The global financial crisis of 2007-2008, the Eurozone crisis and, more recently, the rise of nationalist populism in the world's liberal heartlands have seen general confidence in both economic neoliberalism and liberal democracy wane. It is perhaps too early to judge whether these developments represent a crisis or a new political opportunity for the political project of greening the state. However, retrospective assessments thus far offer a pessimist view (Mol 2016; Paterson 2016). Arthur Mol, for example, has found an overall decline or stagnation of the environmental state in OECD countries since the 1990s in terms of capacity, interest/priority, and authority (Mol 2016)). This includes a general decline or stagnation in levels of expenditure and staffing of environmental ministries and agencies, and in the relative stringency of environmental regulations. He also points out that this decline cannot be fully explained, or compensated for, by the rise of new, non-state and hybrid forms of environmental governance. Matthew Paterson's critical political economy explanation of the prospects of greener states is consistent with this declinist narrative (Paterson 2016). He also argues that ecological sustainability cannot be simply bolted on to the existing functions of liberal capitalist states, let alone emerge as a core state function, because it contradicts the state's imperative to oversee economic growth via private capital accumulation (Paterson 2016: 480). He does, however, recognise the possibility of the greening of governance structures, which may not necessarily take the form of states as classically understood (2016: 488).

Clearly, it is time to take stock of the general research program on the green state, and reexamine some of its assumptions, attentions and methods in the context of these shifts. The articles in this special issue by Dan Bailey, John Barry and Martin Craig each provide a 
significant, timely and critical contribution to this retrospective and prospective stocktaking. This article provides an assessment of their respective contributions while also taking the opportunity to reflect how those seeking to understand the greening (or de-greening) of the state from a critical political economy perspective might extend their critical theory to critical problem-solving in ways that are attentive to the politics of transition. To this end, I play Bailey off against Barry and Craig to illustrate how critical problem-solving might be approached.

Research on the green state thus far has spanned historical inquiry, empirical case studies, large and small-n cross-national studies, sociological explanation and normative theory. Critical theories of the green state have emerged as the most ambitious insofar as they approach empirical research and sociological explanation through a critical normative lens, guided by a general normative purpose of uncovering the social forces and social structures that produce and perpetuate domination (in this case environmental harms and injustices) with a view to transforming such structures. The contributions to this special issue by Bailey, Craig and Barry are all clearly situated in the tradition of critical political economy, with its ultimate roots in Marx, although Barry's contribution to this issue also channels Foucault in providing a 'genealogy of the ideology of economic growth'. All three contributions clearly beckon towards a more dirigiste state, playing a much more active role in orchestrating more sustainable economies and societies. Their respective contributions revisit some of the core questions and assumptions of earlier work on the green state with a view to deepening and widening its critical focus. Their contributions are part of a more general 'widening' wave of research that includes work that has revisited and/or re-envisaged the relationship between the environmental state and the welfare state (Gough 2010; 2016 and 2017; Gough and Meadowcroft 2011; Bailey 2015; Christoff 2017); deepened the critical political economy 
agenda (Newell and Paterson 2010; Paterson 2016); extended the comparative research agendas (Christoff and Eckersley 2011; Bäckstrand and Kronsell 2015; Duit 2014; Duit, Fiendt and Meadowcroft 2016); refocused attention on the politics of transition (Bäckstrand and Kronsell 2015) and widened the geographic scope of inquiry to including the greening of states in developing regions of the world (Death 2016; Chandrashekeran et al. 2017).

Bailey's contribution to this special issue is the most provocative in arguing that the critical green state theory of the 2000s failed to grapple fully with what he calls the 'trilemma of the green state': how to orchestrate degrowth, maintain the fiscal viability of the state while also expanding the environmental functions of the state (see also Bailey 2015). For Bailey, achieving all three objectives is an impossible feat for so long as states remains fiscally parasitic on private capital accumulation, and even more so as they become increasingly indebted. He offers some strategies for politicising and tackling practices of money creation and the viability of existing debt relations, which he rightly notes have been relatively neglected areas in the research on the green state in the 2000s.

Barry, for his part, revisits a basic argument that has been central to the discipline of ecological economics as well as radical environmentalism or ecologism, namely, the critique of economic growth and the fetishization of Gross Domestic Product (GDP) as the overriding measure of collective progress and prosperity. However, this is not a simple repetition of the critique but rather a deeper, historical excavation of the Cold War origins of these economic ideas and how they have worked to shore up ecologically unsustainable capitalist economies. His Gramscian-inspired, historicisation of the ideas of growth and GDP seeks to expose their ideological character and the geopolitical interests that have been served. 
Craig's contribution is more fine-grained in seeking to open-up the black box of the British state, peer inside the administrative apparatus, and expose the internal divisions, hierarchies and struggles within different ministries and agencies in managing the integration of environment and development concerns. Reminding us that states are fractured rather than unitary entities, he shows that some of the biggest obstacles to greening the state lie inside the state itself - in this case the British Treasury - which has largely succeeded in fending off attempts to introduce greener development strategies.

This reply seeks to wrestle with Bailey's trilemma, first, by challenging the how it is framed, and then by drawing selectively on both Barry's and Craig's contributions to suggest how it might be navigated. I begin by drawing to the surface some tensions between the three contributions regarding how the state's dependency on private capital accumulation should be understood theoretically, and how it might be approached methodologically in the politics of transition. I argue that the political project of building greener states will always be a work in progress, and that critical theory therefore needs to develop its own critical method of problem-solving to accompany its critical theory if it is to participate in the politics of transition. This method entails bracketing and holding certain social structures as provisionally given in order focus on political debates and policy prescriptions that are likely to carry high transformative potential. In responding to Bailey's trilemma I illustrate this method by pointing to a more politically credible menu of options that go beyond the binary of growth versus degrowth presented by Bailey.

\section{Building greener states: from critical theory to critical problem-solving}


Whereas the contributions by Bailey and Barry problematise the state's dependence on private capital accumulation, albeit in different ways, Craig's analysis takes it as a given and highlights how the British Treasury has been a major obstacle to greener strategies of accumulation. Implicit in Craig's analysis is the idea that the first steps toward greener states will necessarily entail greener strategies of accumulation. In contrast, Bailey and Barry identify the ceaseless and growth-oriented processes of private capital accumulation upon which states depend as undermining and forever holding back the realisation of fully fledged green states (i.e., states for which ecological sustainability is a central rather than peripheral purpose, which is not to be confused with neoliberal environmental states). In terms of Robert Cox's influential distinction between critical theory and problem-solving theory, Bailey and Barry exemplify the former. To paraphrase Cox (1981), critical theory's task is to problematise the social structures (which include both capitalism and the modern state) that systematically produce social and environmental exploitation, whereas problem-solving theories of the state would take these social structures as background 'givens' and seek policy reforms that would ameliorate effects but not fundamentally address the drivers of environmental problems. Since Craig's account of green development merely looks to change the model of capital accumulation, then it would land on the wrong side of Cox's binary as 'mere problem-solving'.

However, it is usefully to revisit Cox's distinction with a critical eye, since it raises several problems for critical theory in grappling with the politics of transition towards greener states. First, it has had the unfortunate effect (even if it was never intended) of treating problemsolving as a distinctly second-class activity because it is ideologically biased in favour of the status quo, as if critical theory's deeper, structural analysis is objectively correct and therefore free of ideology (Brown and Eckersley 2018: 7). Clearly, this implicit assumption 
cannot stand; critical theorists must articulate and defended the normative purposes that guide their critiques; and if they wish to realise these purposes, then they must approach problemsolving as a further and equally necessary phase of theorising that would follow a more general critique.

Second, Cox's distinction suggests that only structural reforms that can usher in postcapitalist relations will do, and that anything less would perpetuate the status quo. This paints critical theorists into an awkward corner when it comes to the politics of transition, since the depth of the structural transformations of states and markets that the critique requires are, to put it mildly, politically demanding. Ecological problems are 'overdetermined' by the interlocking dependencies between states and markets but it is politically impossible to do everything at once, but anything less would be 'mere' problem-solving. So how might political legitimacy be won for the structural changes that are required, bearing in mind that political support must be mobilised within the distorted arenas of political contestation provided by existing liberal capitalist states that are the primary subject of critique?

Greener states, if they are to emerge, are most likely to be built, piece by piece, as the result of political struggles. This means that they are will always be works in progress or 'works in regress'. The politics of transition is therefore not an interim period or a means to an end state - the green state - but rather an ongoing political condition. If critical theory hopes to shape this politics of transition, then it needs to develop its own account of critical problem-solving based on 'strategic bracketing' of problematic social structures in recognition of the political fact that everything cannot be done at once. By 'strategic bracketing' I mean holding certain social structures as provisionally given, in order focus on policy debates and policy 
prescriptions that are likely to carry high transformative potential. By 'transformative potential' I mean the potential to invite critical reflection and piecemeal reform of any of the many social structures - understood broadly to encompass any recurrent pattern of social activity - that are routinely generating environment degradation and environmental injustices. This includes liberal states and capitalist markets but it also includes discourses (recurrent patterns of meaning) and the subjectivities, rules and practices that they sanction. This would require careful historical and policy analysis of particular state-society complexes, including the particular varieties of capitalism, the character of the political institutions, political cultures (including cultures of risk) and the configuration of 'social forces' in different states, with an eye on identifying particular policy interventions with the most transformative potential in particular contexts. Critical theory should also look for interventions with the potential to 'travel' across different jurisdictions, bearing in mind the increasing convergence around neoliberal economic policies in many OECD countries.

In what follows, I draw on the contributions of Barry and Craig in responding to Bailey's trilemma, and offer one illustration of critical problem-solving by way of a response. The discussion takes it as given that, despite their dependence on capital accumulation, for the foreseeable future states remain the institution with the greatest capacity to discipline capitalism (including investors, producers, and consumers) in order to uphold ecological sustainability (Eckersley 2004: 12). It follows that they need to be kept afloat if they are to be ecologically repurposed.

\section{The trilemma of the green state}


Implicit in the arguments of many environmental nongovernment organisations (NGOs), green party manifestos and policies, and normative theories of the green state is that 'all good things can go together', or at least once the green state is built. While imaginative ecological visions of green states are central to normative debates about repurposing states, I have argued above that the project of greening states will always and necessarily be a work in progress, involving ongoing political struggle, as well as policy learning. However, the trilemma identified by Bailey suggests that such a work in progress is unlikely to progress very far because it is not possible to orchestrate degrowth, maintain the fiscal viability of the state while also expanding the environmental functions of the state. Any attempt to wind back growth will deepen the state's fiscal crisis and shrink its environmental capacity, and we have already seen a general decline in environmental capacity from the high-water mark of the 1990s (Mol 2016).

For Bailey, the only path out of this trilemma is to move to a post-capitalist economy. Building on the work of Dryzek (1992), Hay (1996) and Paterson (2016), he argues that the functional dependence of the state on capitalist growth must be grasped at the ontological level because capitalism and the state are co-constitutive. Governments will always have to find ways of managing the inherent tension between the accumulation and legitimation imperatives to stay in power, which means maintaining economic growth while also addressing some of the harmful social and environmental consequences of growth, and both are required to maintain political legitimacy. However, these tensions cannot be solved while states remain fiscally dependent on private capital accumulation, so policy prescriptions that fail to move economies in a post-capitalist direction would necessarily amount to mere problem-solving in Cox's terminology.

Indeed, the trilemma is even more daunting than Bailey has outlined once other fiscal challenges facing the state are brought into view. In his examination of the relationship 
between the welfare state and what he calls 'the climate state', Peter Christoff (2017) has argued that the level of public indebtedness arising from the social welfare functions of states is expected to continue its upward trajectory due to a range of endogenous and external pressures. $^{2}$ This indebtedness will be further compounded by intensifying climate-related problems. Christoff argues that these enhanced and additional fiscal pressures can be expected increasingly to challenge the state's capacities to meet demands for conventional welfare and environmental expenditure. While some OECD states have recognised the costs of mitigation, and to a lesser extent, adaptation in their medium and longer-term budget forecasts, their responses typically fall well-short of what is required. However, very few states have contemplated, let alone attempted to estimate and include in their budget forecasts, the costs of loss and damage arising even from the global warming that is already 'locked in' (Christoff 2017). These costs are expected to escalate the longer it takes the parties to the Paris Agreement 2015 to reduce their collective emissions. Given that time is of the essence, then critical problem-solving on how this trilemma might be creatively navigated is crucial to the project of building greener states.

Yet, in a different sense, the dilemma is also less daunting that Bailey presents because his analysis has closed off more politically fruitful options for critical problem-solving by presenting a very stark and limited choice between growth or degrowth, as if there are no alternatives. He assumes that the purpose of the green state is orchestrate 'strong ecological modernisation' and that this means reducing GDP growth to reduce the systematic generation

\footnotetext{
${ }^{2}$ These include the competitive pressures of economic globalisation, the changing nature of work due to technological change, increasing inequalities in income and wealth within and between states, demographic change, and the need for further investment in aging public infrastructure.
} 
of environmental harms. Since this would necessarily produce a suppression of economic activity and a reduction or flat-lining in the tax take, it would be self-defeating because it would undermine environmental state capacity. 'Green growth' will not do because it merely seeks the decoupling of environmental degradation from economic growth while otherwise leaving intact the growth-oriented capitalist economy represents. It must therefore be dismissed as a weak form of technocentric ecological modernisation that works with rather than against the growth imperative of capitalism.

While we can agree with his critique of green growth, it does not follow that degrowth is the only ecologically viable option. In the English language, 'growth' and cognate terms like 'progress' and 'development' enjoy positive connotations, while their antonyms (such as degrowth, statis, regress) are likely to be non-starters in the politics of transition. There is no reason why the positive connotations of growth cannot be harnessed, but with different adjectives and therefore different meanings. These might then provide a warrant for governments, as economic managers, to orchestrate good/healthy/desirable growth and deorchestrate bad/desirable/harmful growth - in short, grow the good and degrow the bad. Thus far, the conventional discourse of green growth has avoided any engagement with what should happen to the rest of the economy as new green industries bloom, and it uncritically accepts GPD as the measure of growth. The assumption is that ecologically harmful industries would eventually wither or be overtaken by the new industries without a fight. In contrast, the selective and simultaneous orchestration of 'growing and degrowing' would entail actively encouraging the growth of industries that hasten and enable environmental protection (such as renewable energy, environmental services and other industries that engaged in closed loop production) and overseeing the contraction and phasing out of ecologically harmful industries (such as fossil fuel extraction, production and consumption, and the plastics packaging industry). The phasing in and phasing out processes would need 
to be carefully managed, both discursively and in terms of policy timing, to prevent major economic disruption, ensure a just transition and avoid political backlash, and in ways that would maintain the state's fiscal viability. After all, the point of strong or reflexive ecological modernisation is to maintain the conditions for the reproduction of societies, their steering systems, and the ecosystems in which they are embedded and upon which they depend. This necessarily entails maintaining the reflexive capacity of social steering systems, and states remain the pre-eminent steering system.

Of course, Bailey would not disagree with this proposition; my point is simply that his framing of the choices arising from the trilemma is too constricted and forecloses this kind of reflexive economic steering. As it happens, Bailey's own response to the trilemma might be seen as consistent with what I have defended as critical problem-solving. He floats two proposals that directly challenge the power of private capital in an effort to nudge the economy in a post-capitalist direction. The first proposal draws on New Monetary Theory, which critically examines the role of private banks in creating new money for private capital accumulation. Debt-based and interest-bearing money creation are dependent on ongoing economic growth. Bailey suggests that if the power of money creation were to be transferred to the state, and used for public purposes such as new energy systems and low carbon infrastructure, then the state would become less dependent on taxation revenue and borrowing and correspondingly freer to build environmental capacity.

The second proposal entails a politicisation of 'debt fetishism' by exposing the ways in which debt creates, perpetuates and 'naturalises' relations of economic exploitation and domination. The more states become indebted, the more they are at the mercy of financial markets, currency speculators and credit rating agencies. Bailey argues that debt aversion is a deeply embedded norm in capitalist societies - one that has become depoliticised and nonnegotiable, even in situations where debt is 'odious' and clearly fails to serve the interests of 
the public. He argues that if we are to move beyond growth, then it is necessary to politicise debt by exposing the unjust power relations that enable certain owners of capital to enjoy profits while imposing misery on others, and he offers the idea of 'debt audits' that can expose cases of 'odious debt'. Bailey does not seek to be too prescriptive and his proposals are offered as illustrations of a 'minimalist route' to challenging and reducing some of the functional dependencies of the state on private capital accumulation; and states would still need to manage inflation.

Bailey has opened an important new front of inquiry in research on the green state. An examination of the relationship between monetary policy, debt and the fiscal crisis of the state has thus far been largely neglected (one recent exception is Mary Mellor [2017]). Perhaps, in the wake of the global financial crisis, there are new opportunities for winning political legitimacy for such proposals. However, one must ask, in the move from critical theory to critical problem-solving, whether his proposals are the best place to start. If states that are already heavily indebted are given the power of money creation, then how might inflation be kept under control? And if odious debts are to be exposed, and the deeply embedded norm that debt must be repaid is to be politicised, would this also give a license to states to borrow with impunity?

The virtues of pursuing a simultaneous strategy of growth and degrowth is that it also opensup the potential to re-politicise how we measure growth, and therefore has significant transformative potential. The ecological critique of GDP is hardly new, and nor is the case for a new Genuine Progress Indicator, which builds on the Index of Sustainable Economic Welfare pioneered by Herman Daly and John Cobb (1989), so they need not be rehearsed again in detail here (see, for example, Victor 2008; Jackson 2009). Rather, the general point is that focussing public attention on what is and is not measured in national accounts invites critical reflection on fundamental questions about what collective progress and prosperity 
should mean, how we might best measure it and what role the state should play in facilitating or orchestrating it. It also invites reflection on the limits of measurement (how can contentment or happiness be measured?). Proposals for a new Genuine Progress Indicator also have the potential to travel across different jurisdictions while enabling adaptation to local contexts. A discursive rearticulation of ultimate economic ends (say durable or sustainable prosperity), while remaining provisionally agnostic about economic means, can unsettle exclusionary binaries (such as growth versus edgrowth) and open-up more politically productive categories that side-step entrenched political antagonisms (Glasson 2015; Ferguson 2015). A political debate about the appropriate meanings and measures of durable or sustainable prosperity, along with their limitations, also provides new opportunities to expose the lack of accountability by both states and corporations for the ecological harms that are passed on through time and space. However, to create the necessary opening for such a debate, it is first helpful to historicise existing ideas and measures of economic growth. And it is here that Barry's chapter provides some important clues.

\section{Economic orthodoxy versus economic heterodoxy}

Barry shows how the idea of economic growth, as measured by GDP, is a relatively recent invention (see also Ferguson 2014) and he seeks to lay bare the ideological work that these new categories have performed. He tracks how the idea of GDP emerged in the Roosevelt administration during the Great Depression as a means of addressing mass unemployment, and how it was later enlisted to track production to aid the US and UK in mobilising resources for World War II. Thereafter GDP became an important plank in US foreign policy in the post-World War II period to shore up the western sphere against the Soviet Union. Indeed, recipients of aid under the Marshall plan had to submit to the US's system of national 
economic accounting. The further refinement and propagation of the methodology for measuring GDP was performed by a transnational epistemic community of economists working for the OECD until the System of National Accounts was standardised by the United Nations. As Barry puts it, in its promotion of GDP, the OECD became the 'economic arm of NATO' during the Cold War. GDP was also the measure used to demonstrate the superiority of capitalist economies over communist economies with the end of the Cold War. Despite the warnings by Simon Kuznet, who played a major role in creating the system of national accounts (and argued that it should not be taken as a reliable measure of welfare), economic growth as measured by GDP is now widely perceived as an objective necessity rather than a social construction, and a political imperative rather than a political choice.

Barry's implicitly Gramscian political economy critique treats economic growth as a hegemonic discourse that claims to serve society in general, but in reality works to favour the interests of certain economic classes and elites while producing economic and social inequalities and unsustainable economies. Yet the material covered by Barry might have been analysed with similar critical effect via a Foucauldian lens to reveal the disciplinary power of new categories of economic knowledge. Either way, his analysis provides a warning that critical theories of the state should not fall into the trap of reifying problematic categories by, for example, treating the accumulation function of states as an objective imperative as distinct from a social construction. The deconstruction of reified categories to show that things can be otherwise is a necessary precursor to the reconstruction and normative defence of more ecologically productive categories of economic thought and practice. The new field of heterodox economics, which includes ecological economics, has been in the vanguard of revitalising economic theory and practice along these lines. However, there are some powerful gate-keepers that seek to uphold existing orthodoxies, as Craig's contribution to this special issue makes clear. 


\section{The state economic gate-keepers}

Martin Craig's empirical study of the hierarchy of ministries inside the British state seeks to understand to what extent green development strategies have been attempted and why they rarely get off the ground. As previously noted, he takes it as given that public policy is necessarily made in the context of capitalist economies, which means that moving towards greener development strategies necessarily means producing more ecologically sustainable accumulation strategies. However, Craig's understanding of green development means much more than 'green growth'; it entails the active orchestration of new patterns of demand and supply that satisfy social, economic and ecological goals and therefore goes beyond weak, technocentric ecological modernisation. In this respect, it is an example of critical problemsolving because it is a potentially transformative transition strategy that works (provisionally) with the grain of existing market economies while redirecting markets to conform to politically determined goals of sustainability.

That said, his findings are sobering. Efforts by environmental and other ministries to promote greener development strategies have been systematically blocked by Treasury's strong proclivity to favour a strategy of repairing the existing accumulation strategies rather than developing greener strategies. This includes responding to economic crises by 'recovery through regressive accumulation', which entails privileging the profitability of financial capital at the expense of productive capital. This strategy shies away from financing industrial or ecological modernisation or 'picking winners' in favour of policing and minimising government spending and focusing on a very narrow band of short-term macroeconomic gains in GDP growth at the expense of considering the long-term social, economic and environmental benefits of enhanced investment in green infrastructure or green 
industries. So while Craig makes it clear that greener development requires purposive economic orchestration by governments, the dominance of the British Treasury in shaping and constraining overall policy direction is routinely thwarting the possibility of such purposive orchestration.

Matthew Paterson has argued that a political economy analysis of the green state should start by examining its conditions of possibility, 'and the routes by which it might be pursued' (2006: 480). He suggests that this would entail "the pursuit of "an ecological regime of accumulation" ... [which] would be the political economy equivalent of ecological modernisation' (2016: 480). But he also argues, in keeping with Bailey, that this would be a strategy that is 'driven by an ongoing tension between different accumulation and legitimation imperatives that are frequently in contradiction with each other' (2016: 480). Aside from noting that this contradiction is not necessarily invariable, should we treat the push back by Treasury as evidence of a contradiction?

For his part, Craig acknowledges that the problem is not simply an obstructionist Treasury. It is also necessary to delve into the professional economic training (and we might add social and political networks) of Treasury officials, the nature of their organisational environment and, of course, the priorities of the government and not just those of the Chancellor of the Exchequer. To this one must add the nature of party competition inside the parliament, and beyond, the configuration of business interest groups and their relative political strength visà-vis other social forces in civil society.

This list of reasons is long enough to make a more general point: that opposition to greener strategies of accumulation inside the British state cannot, and should not. be reduced to the tensions between the accumulation and legitimation functions of the state, even if they play a role. In any event, there are multiple ways in which these tensions might be framed and 
managed. Both Craig's and Barry's contributions provide a timely reminder not to think in terms of economic necessities or imperatives but rather in terms of political choices that have been politically constructed as necessities by those with the social structural, institutional and discursive power to define what is necessary. This means that the legitimation challenge of rethinking and reframing economic policy in ways that are consistent with ecological sustainability is intimately related to the very meaning of the accumulation challenge.

Critical political economy, of course, does not focus on everything: rather, it focuses on the ways in which the mutual dependencies between states and ongoing private capital accumulation have systematically generated ecological problems. Yet the roots and the drivers of the global ecological crisis are deeper, more extensive and more tangled that these mutual dependencies. Although the neoliberal phase of globalisation has certainly produced an acceleration in the intensity and extensity of processes of modernisation (including economic specialisation and exchange), along with ecological degradation, these processes can be traced to the early modern period and include 'the rise of instrumental rationality, new scientific inquiry [and the increasing specialisation of knowledge and expertise], technological development, the rise of the modern state, industrialisation (in both its capitalist and communist forms), and significant changes in culture, identity and the human relationship to the larger nonhuman world' (Christoff and Eckersley 2013: 9). Addressing the global ecological crisis requires reflexive ecological modernisation across all these domains given their mutual but uneven interpenetration.

Strong or reflexive ecological modernisation is therefore much more than the production of ecologically reflexive economic policy. It entails critically confronting the many ways in which the environmental effects of the modernisation process are increasingly threatening the stability and viability of the modernisation process itself. This includes 'critically confronting and transforming the processes of knowledge generation and dissemination, the forces of 
production, the relations of production and the relations of definition (who defines and manages ecological risks) in ways that are more risk-averse, and more accountable to those who may potentially suffer the consequence of unelected risks' (Christoff and Eckersley 2013: 30). In relation to the project of building greener states, it entails critically deconstructing, exposing and discursively reframing the state's role as an economic, social and environmental manager in ways that will keep it afloat in the ongoing politics of transition while also opening-up new pathways of transformation. Critical problem-solving is a necessary and crucial phase of critical theory that entails looking for the next, best policy steps that might be taken take to foster this reflexive process.

\section{Conclusion}

This reply has suggested that the trilemma of the green state outlined by Bailey is both more and less daunting than he envisages. It is more daunting once the fiscal pressures on the state arising from climate change are factored in. It is less daunting and more manageable if the challenge is presented not as a stark choice between growth versus degrowth but rather between good/desirable/healthy versus bad/desirable/harmful growth.

However, there is another trilemma that has thus far escaped attention, and which is associated with the legitimation challenge facing democratically elected governments, namely, that it is impossible to satisfy simultaneously robustness to pluralism, a democratic decision procedure while also guaranteeing ecologically sustainability (see, for example, Wissenburg 1998; Lundqvist 2004; Wong 2016). While many green political theorists have argued that ecology and democracy can be made more compatible by strengthening representation, transparency and accountability and extending them across time and space, 
ecologically rational governance is clearly beyond the reach of liberal democracy as we know it. This further underscores the need for critical problem-solving that is attentive to this legitimation challenge (which includes being attentive to pluralism and recognising that there is more than one route to sustainability).

Finally, building political legitimacy for more dirigiste states to build more ecologically sustainable economies and societies has proved to be much more challenging that it has been for the building the welfare state. The latter was largely a national creation designed to serve national purposes, and could be defended as a nation-building project where the benefits are exclusively enjoyed by citizens. In contrast, the green state is increasingly an international creation produced by a growing raft of multilateral environmental treaties, declarations, and now sustainable development goals (Meadowcroft 2005, 12-13), and it is expected to act as a local agent in defence of the global environment (Eckersley 2004). If the welfare, environmental and climate functions of the state, as currently understood, are to be thrown into more intensive competition for increasingly scarce budgetary resources, then the social movements seeking to build and legitimate greener states will need to highlight their interdependencies in more systematic and creative ways to minimise trade-offs.

It should therefore be clear that the project of building greener states is becoming more, not less, challenging over time, and in a context where time is increasingly of the essence in the case of irreversible global ecological problems like climate change and biodiversity loss. The contributions by Bailey, Barry and Craig in this special issue have helped to lay bare many of these challenges but the hard work of critical problem-solving still lies ahead. 


\section{References}

Bäckstrand, K. and Kronsell, A. (eds.), (2015), Rethinking the Green State: Towards Climate and Sustainability Transitions (Abingdon: Routledge).

Bailey, D. (2015), 'The Environmental Paradox of the Welfare state: The Dynamics of Sustainability', New Political Economy, 20 (6), pp. 793-811.

Barry, J. and Eckersley, R. (eds.) (2007), The State and the Global Ecological Crisis. (Cambridge, MA: MIT Press).

Brown, C. and Eckersley, R. (2018), 'International Political Theory and the Real World', The Oxford Handbook of International Political Theory, edited by Chris Brown and Robyn Eckersley (Oxford: Oxford University Press), pp. 3-18.

Chandrashekeran, S. Morgan, B. Coetzee, K. and Christoff, P. (2017), 'Rethinking the Green State Beyond the Global North: A South African Climate Change Case Study', WIREs Climate Change, 8:e473. doi: 10.1002/wcc.473

Christoff, P. (2017), 'The Climate State: Global Warming, Fiscal Crisis and the Future of the Welfare State', Paper presented at the Potsdam Institut fur Klimafolgensforschung, 26 June.

Christoff, P. and Eckersley, R. (2011), 'Comparing State Responses', in John S. Dryzek, Richard B. Norgaard, and David Schlosberg (eds.) The Oxford Handbook of Climate and Society (Oxford: Oxford University Press), pp. 431-448. 
Christoff, P. (1996), Ecological Modernisation, Ecological Modernities', Environmental Politics, 5 (3), pp. 476-500.

Cox, R. (1981), 'Social Forces, States and World Order: Beyond IR Theory', Millennium: Journal of International Relations, 10 (2), pp. 126-55.

Daly, H. and Cobb, J. (1989), For the Common Good: Redirecting the Economy Toward Community, the Environment, and a Sustainable Future (Boston: Beacon Press)

Death, C. (2016), The Green State in Africa (New Haven: Yale University Press).

Dryzek, J.S. Downes, D. Hunold, C. Schlosberg, D. and Hernes, H. K. (2003), Green States and Social Movements: Environmentalism in the United States, United Kingdom and Norway (Oxford: Oxford University Press).

Duit, A. (2014), State and Environment the Comparative study of Environmental Governance (Cambridge, MA: MIT Press).

Duit, A. (2016), 'The Four Faces of the Environmental State: Environmental Governance Regimes in 28 Countries', Environmental Politics, 25 (1), pp. 69-91.

Duit, A., Feindt, P. H. and Meadowcroft, J. (2016), 'Greening Leviathan: The Rise of the Environmental State?', Environmental Politics, 25 (1), pp. 1-23 
Eckersley, R. (2004), The Green State: Rethinking Democracy and Sovereignty (Cambridge, MA: MIT Press).

Ferguson, P. (2015), 'The Green Economy Agenda: Business as Usual or Transformational Discourse?', Environmental politics 24(1): pp. 17-37.

Ferguson, P. (2014) The State and the Growth Hegemony: Prospects for a Post-Growth Society. PhD Thesis, University of Melbourne.

Glasson, B. (2015), 'Subversive Rearticulation between Radicalism and Reform: The Case of Ecologism', Journal of Political Ideologies, 20 (2), pp. 156-78.

Gough, I. (2017), Heat, Greed and Human Need: Climate Change, Capitalism and Sustainable Wellbeing (Edward Elgar)

Gough, I. (2016), Welfare States and Environmental States: A Comparative Analysis', Environmental Politics, 25 (1), pp. 24-47.

Gough, I. (2010), 'Economic Crisis, Climate Change and the Future of Welfare States', 21st Century Society, 5 (1), pp. 51-64.

Gough, I. and Meadowcroft, J. (2011), 'Decarbonizing the Welfare State', in J. Dryzek, R.B. Norgaard and D. Schlosberg (eds), Oxford Handbook of Climate Change and Society (Oxford University Press), pp. 490-503. 
Hunold, C. and Dryzek, J. S. (2002), 'Green political theory and the state: context is everything'. Global Environmental Politics, 2 (3), pp. 17-39.

Jackson, T. (2009), Prosperity Without Growth: Economics for a Finite Planet (London: Earthscan, 2009).

Lundqvist, L. J., (2001), 'A Green Fist in a Velvet Glove: The Ecological State and Sustainable Development', Environmental Values, 10 (4), pp. 455-472.

Lundqvist, L. J., (2004), Sweden and Ecological Governance: Straddling the Fence. (Manchester: Manchester University Press).

Meadowcroft, J. (2008), 'From Welfare State to Environmental State', Journal of European Social Policy 18 (4), pp. 325-44.

Meadowcroft, J., (2005), 'From Welfare State to Ecostate?' In J. Barry and R. Eckersley, eds. The State and the Global Ecological Crisis (Cambridge, MA: MIT Press), pp. 3-23.

Meadowcroft, J., (2012), 'Greening the State', in P. Steinberg and S. VanDeveer, (eds.) Comparative Environmental Politics (Cambridge, MA: MIT Press), pp. 63-88.

Mellor, M. (2017), 'Money for the People. Great Transition Initiative: Toward a Transformative Vision and Practice', (August). Available at: http://www. greattransition.org/publication/money-for-the-people 
Mol, A.P.J., (2016), 'The Environmental Nation State in Decline', Environmental Politics, 25 (1), pp. 48-68.

Newell, P. and Paterson, M. (2010), Climate Capitalism: Global Warming and the Transformation of the Global Economy ((Cambridge: Cambridge University Press).

Paterson, M. (2016), 'Political Economy of Greening the State', in T. Gabrielson, C. Hall, J. M. Meyer and D. Schlosberg, eds. The Oxford Handbook of Environmental Political Theory. (Oxford: Oxford University Press).

Paehlke, R. and Torgerson, D., (2005), Managing Leviathan: Environmental Politics and the Administrative State. 2nd ed. New York: Broadview.

Schnaiberg, A., Pellow, D.N., and Weinberg, A., (2002), 'The Treadmill of Production and the Environmental State', in A.P.J. Mol and F. Buttel, eds. The Environmental State Under Pressure (Bradford: Emerald), pp. 15-32.

Schnaiberg, A., (1980), The Environment, from Surplus to Scarcity (New York: Oxford University Press).

Victor, P.A. (2008), Managing Without Growth: Slower by Design, Not Disaster (Cheltenham, UK: Edward Elgar).

Wissenburg, M. (1998), Green Liberalism: The Free and the Green Society, London: UCL Press. 


\section{University Library}

\section{- M M I N E R VA A gateway to Melbourne's research publications}

Minerva Access is the Institutional Repository of The University of Melbourne

Author/s:

Eckersley, R

Title:

The Green State in Transition: Reply to Bailey, Barry and Craig

Date:

2020-01-02

Citation:

Eckersley, R. (2020). The Green State in Transition: Reply to Bailey, Barry and Craig. New

Political Economy, 25 (1), pp.46-56. https://doi.org/10.1080/13563467.2018.1526270.

Persistent Link:

http://hdl.handle.net/11343/261040 